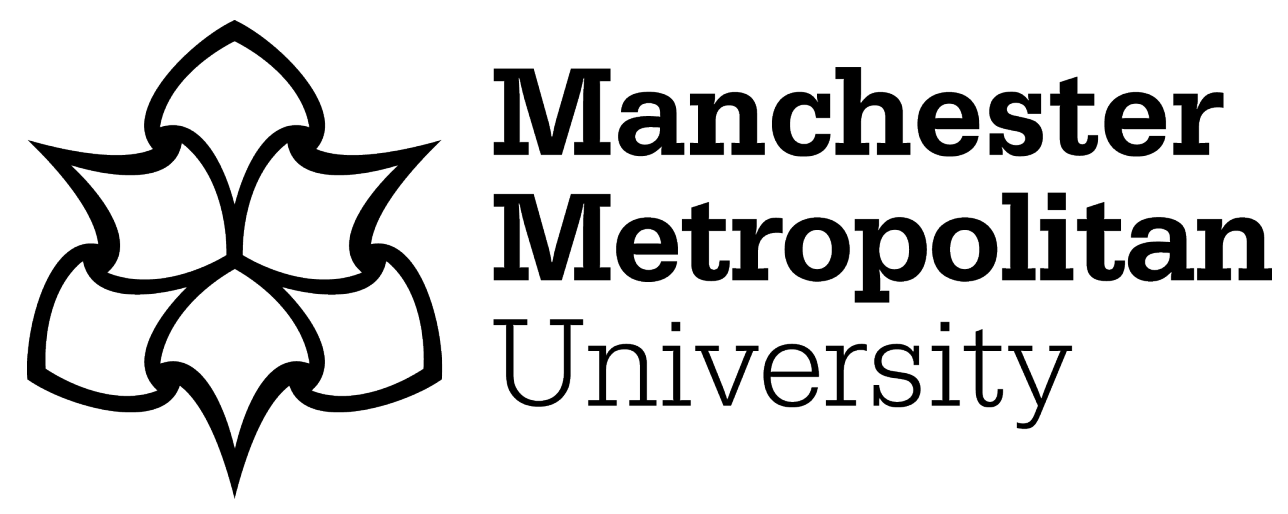

Diamond, Alana and Wong, Kevin (2000) Violence against women: The Crime Reduction Programme Initiative. Criminal Justice Matters (CJM), 42. pp. 16-17. ISSN 0962-7251

Downloaded from: https://e-space.mmu.ac.uk/622255/

Version: Published Version

Publisher: Centre for Crime and Justice Studies

Please cite the published version 


\title{
Violence Against Women: The Crime Reduction Programme Initiative
}

\author{
Alana Diamond details the basis of the CRP's Violence Against \\ Women Initiative. Kevin Wong outlines successful and newly \\ commissioned projects.
}

$\mathrm{T}$

he Reducing Violence against Women Initiative is part of the Home Office's Crime Reduction Programme (CRP) which was announced by the Home Secretary, Jack Straw in 1998. The aim of the Violence against Women Initiative is to identify the most appropriate and cost effective approaches to reducing domestic violence, rape and sexual assault by known perpetrators. Like other CRP initiatives 'Violence against Women' has commissioned and will independently evaluate multiagency projects to provide evidence of effectiveness. This, in turn, will provide models of good practice for replication elsewhere. For the purposes of this initiative the Home Office definition of domestic violence is used. This is any violence between current or former partners in an intimate relationship, wherever and whenever it occurs. The violence may include physical, sexual, emotional, psychological or financial abuse. Of all violent crime experienced by women, 43 per cent is domestic (MirrleesBlack, 1999). Over a lifetime 22.7 per cent of women, and 14.9 per cent of men reported being a victim of domestic assault (MirrleesBlack, 1999).

\section{Review of existing knowledge}

A series of literature reviews were commissioned in the spring of 1999 , to inform strategically the development of the initiative. The reviews covered: assessing and managing the risk of domestic violence; the use of criminal law; civil law remedies; policing domestic violence; accommodation provision; health services; multi-agency fora; outreach and advocacy approaches; women survivors' views; meeting the needs of children; perpetrator programmes and monitoring costs and evaluating needs. The reviews highlighted the lack of robustly evaluated studies on what works, particularly in the UK, and an almost complete lack of information about cost-benefit and cost-effectiveness. However, they did reveal some promising approaches to tackling domestic violence, as well as identifying the selection criteria for the projects. These included, for example, a multi-agency holistic approach strategically integrating responses by the police, service providers and the Crown Prosecution Service (CPS). This involved users in safety planning, taking into account children's welfare and protection. Other potential strategies included: appropriate targeting of responses using previous victimisation and separation as indicators of future risk; early identification through the health service and primary care; making better use of civil as well as criminal law; and enhanced evidence gathering. (Home Office, 2000).

A review of the literature on rape and sexual assault provided the rationale for the rape and sexual assault by known perpetrators' part of the programme. The literature suggested that there were increasing numbers of incidents of reported 'acquaintance rape', survivors were more likely to be relatively young and there were problems of attrition related to prosecution (Women's Unit, 1999.
Harris and Grace,1999; Grace, Lloyd and Smith, 1992).

\section{Project development}

Independent consultants, acting as project developers, have been commissioned for each project package. Their role is to ensure programme integrity, that is that the project meets its own and the CRP's aims and objectives. Project developers will provide professional advice and support and will ensure the project can be evaluated. They will take responsibility for much of the initial data categorisation, standardisation and the development of monitoring and tracking systems. Developers will also facilitate the relationship between the projects, the evaluators and the Home Office Team. Project developers will be asked to provide advice and support during the first five or so months of the life of a project, which are crucial. This is when strategic decisions are being made, and data systems are being developed.

\section{Evaluation}

Independent teams are currently being commissioned to fully evaluate the project packages. They will also examine cost effectiveness and compare common themes and recommendations for each project package. Initial findings from the programme will be available in early 2003.

Alana Diamond is the Programme Director of the Violence against Women Initiative in the Policing \& Reducing Crime Unit in the 
Research Development \& Statistics Directorate of the Home Office.

\section{References:}

Grace, S., Lloyd, C., and Smith, L. (1992), Rape: From Recording to Conviction. London: Home Office.

Harris, J., and Grace, S. (1999), A question of evidence? Investigating and prosecuting rape in the 1990s. London: Home Office.

Home Office (2000), Reducing Domestic Violence: What Works? Briefing Notes. London: Home Office. www.homeoffice.gov.uk/ violenceagainstwomen/crp/htm

Mirelees-Black, C. (1999), Domestic Violence: Findings from a new British Crime Survey self completion questionnaire. London: Home Office.

Women's Unit (1999) Living without Fear: an integrated approach to tackling violence against women. London: Cabinet Office.

\section{New Projects to Deal with Violence Against Women}

\section{'Women have a right to live their lives without the fear of violence' (Jack Straw)}

According to the Government one in four women experience domestic violence at some stage in their lives, seven out of ten women under 30 worry about being raped and every week two women are killed by their current or former partners.

The Government's campaign to tackle violence against women was kick started by the publication in June 1999 of Living without fear - An integrated approach to tackling violence against women.

Since then funds have been allocated within the Crime Reduction Programme to develop solutions to reducing violence against women. A bidding round in March this year produced 34 successful projects from 214 applicants.

Funds became available in July and the initiatives have Home Office funding till March 2002. As with other strands of the Crime Reduction Strategy projects have been selected on the basis of testing out practice, the transferability of learning and the capacity to deliver tangible results within the Government's 'What Works' framework.

The successful schemes have been grouped into nine themes for the purposes of development support and evaluation. These include education and awareness raising, health, prevention and protection and rape services.

Amongst the projects, four have been selected which provide outreach interventions in rural areas such as Buxton and St Austell; three address the needs of women from black and racial minority groups; one project will develop a treatment programme for young male offenders; and one will establish a national data collection and monitoring system for the Rape Crisis movement in England and Wales.

Other projects are developing a virtual access centre to provide advice and support; risk assessment and screening tools; a drama vehicle for pupils in year 11; an evidence gathering scheme for GPs in Salford; and a forensic nurse examiner service.

These projects are part of the Government's wider programme of activity to deal with violence against women, which during this year has included guidance on the collecting and managing of data, multi-agency guidance for addressing domestic violence launched in March by Paul Boateng MP, and a revised circular to police forces in May highlighting good practice in dealing with incidents of domestic violence.

Kevin Wong is a Programme Development Manager for Nacro, and a member of the team providing technical assistance to the Violence Against Women Initiative. 